\title{
Osmotic demyelination syndrome: plasmapheresis versus intravenous immunoglobulin?
}

\author{
Kunakorn Atchaneeyasakul ${ }^{1} \cdot$ Anita Tipirneni $^{1} \cdot$ Salomon Gloria $^{1}$. \\ Andrew C. Berry ${ }^{2} \cdot$ Kush Shah $^{3} \cdot$ Dileep R. Yavagal ${ }^{1}$
}

Received: 25 March 2016/Accepted: 5 April 2016/Published online: 18 April 2016 (C) SIMI 2016

A 63-year-old man with a past medical history of nonalcoholic steatohepatitis cirrhosis complicated by hepatic encephalopathy and non-bleeding esophageal varices presented for orthotopic liver transplantation. The patient had no acute complications in the immediate post-operative period, and was extubated on post-operative day (POD) 1 . At that time, he was neurologically intact, alert and oriented and with no focal neurological deficits. On POD 3, he became lethargic and quadriplegic (Medical Research Council Scale Grade 0), and developed right-sided focal seizures with secondary generalization. His serum sodium was $128 \mathrm{mmol} / \mathrm{L}$. He was re-intubated, and treated for his seizures with lorazepam $4 \mathrm{mg}$ and levetiracetam $2 \mathrm{~g}$, and then continued on levetiracetam $1 \mathrm{~g}$ two times a day. The following day, he was unresponsive and had no motor response to painful stimuli. His serum sodium had corrected without additional exogenous intervention to $135 \mathrm{mmol} / \mathrm{L}$. On post symptom onset day (PSOD) 3, an MRI brain without contrast showed chronic small vessel ischemic changes but no other abnormality (Fig. 1a). The EEG did not show any seizure or epileptiform discharges. Serum chemistry and cerebrospinal fluid analysis did not show any significant abnormalities. On PSOD 13, his presentation remained the same. An MRI brain was repeated showing DWI restriction and high T2 signal in the

Andrew C. Berry

aberry5555@gmail.com

1 Department of Neurology, Jackson Memorial Hospital, University of Miami School of Medicine, Miami, FL, USA

2 Department of Medicine, University of South Alabama, 2451 Fillingim St., Mobile, AL 36617-2238, USA

3 Department of Radiology, Jackson Memorial Hospital, University of Miami School of Medicine, Miami, FL, USA central pons, suggestive of ODS (Fig. 1b). On PSOD 19, he was started on both IVIG and PP for a total of 5 days. Approximately 3 weeks after treatment with IVIG and Plasmapheresis, a repeat MRI showed similar prominence of T2 hyperintensity in the central pons with sparing of the periphery as compared to prior, findings consistent with central pontine myelinolysis/osmotic demyelination syndrome (Fig. 1c). Over the next 90 days the patient improved, becoming fully alert, regaining spontaneous muscle flicker in all four extremities (Medical Research Council Scale Grade 1), full eye movements and the ability to swallow.

Osmotic demyelination syndrome (ODS) is a disorder characterized by the destruction of neuronal myelin sheaths in either the central area of the pons as in central pontine myelinolysis (CPM), or in other susceptible areas such as the basal ganglia, hippocampi or cerebellum known as external pontine myelinolysis (EPM). CPM can present with T2 hyperintensities on MRI in a classic trident-shape pattern. ODS usually presents as a complication of rapid correction of hyponatremia. Although no specific treatment has been described, plasmapheresis (PP) and intravenous immunoglobulin (IVIG) have been suggested as possible options for the management of ODS [1]. A clear association has been established between rapid correction of hyponatremia and the development of ODS. Although not completely understood, the pathophysiology of ODS classically described is the reduced extracellular osmolality causing brain cells to release osmotically-active substances in an attempt to achieve osmotic equilibrium. These osmotic substances cannot be reabsorbed rapidly, and when sodium levels are increased, they create an osmotic stress that leads to a disruption in the blood brain barrier, leading to myelinolysis. In addition, the death of oligodendrocytes via apoptosis from osmotic shifts has also been suggested 

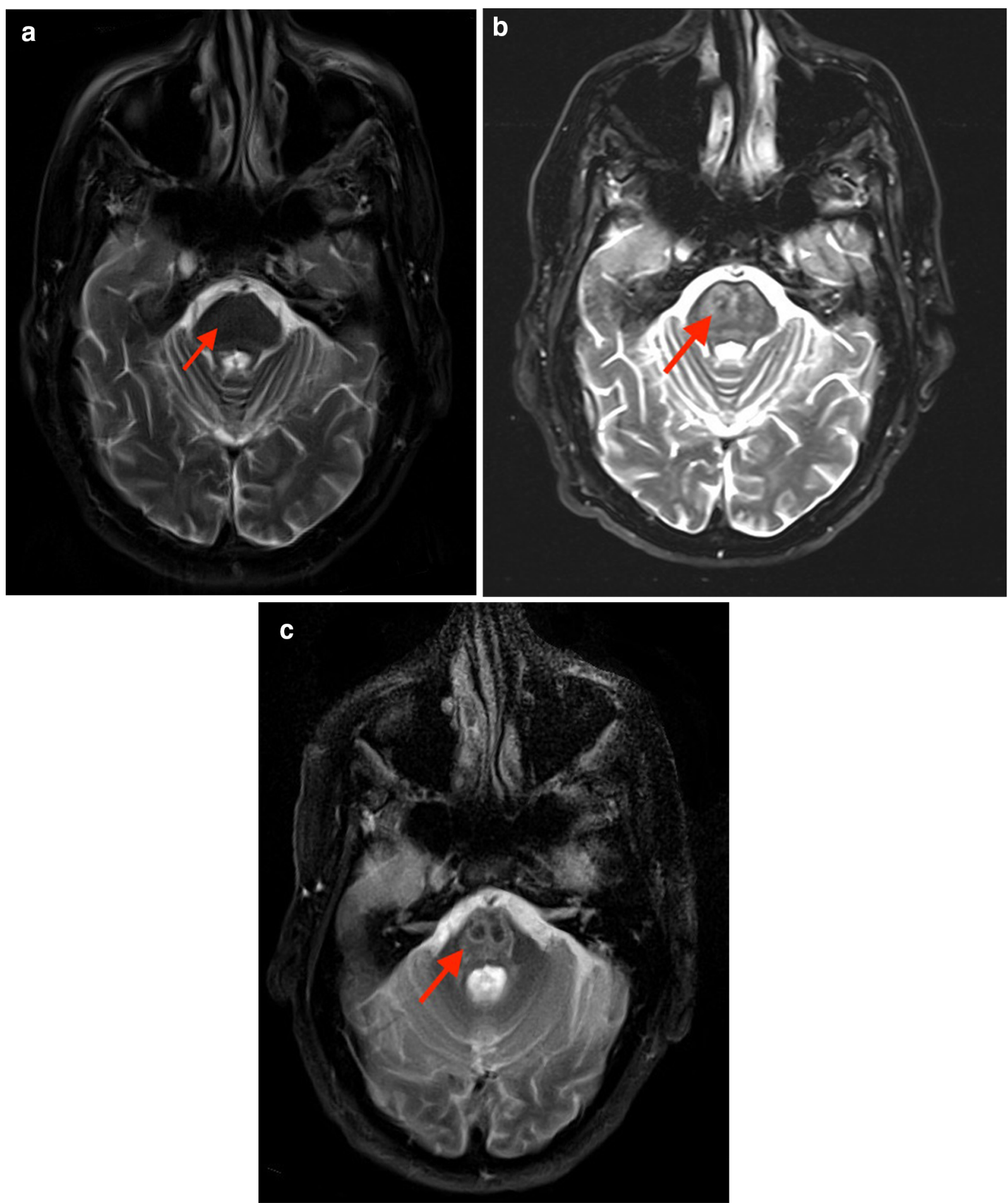

Fig. 1 a Post symptom onset day 3. MRI normal T2 appearance of the central pons without evidence of hyperintensity. b Post symptom onset day 13. MRI confluent T2 hyperintensity in the central pons findings consistent with central pontine myelinolysis/osmotic demyelination syndrome, possibly subacute. c Approximately

as an additional mechanism that contributes to the pathophysiological process. In our patient, the hyponatremia was corrected itself without additional exogenous intervention
3 weeks after treatment with IVIG and plasmapheresis. MRI similar prominence of $\mathrm{T} 2$ hyperintensity in the central pons with sparing of the periphery as compared to prior, findings consistent with central pontine myelinolysis/osmotic demyelination syndrome

from 128 to $135 \mathrm{mmol} / \mathrm{L}$ within $24 \mathrm{~h}$ (on day 3). We suspect this resulted from rapid volume and electrolyte fluctuation due to liver transplantation. By the time the 
Table 1 Summary of all reported osmotic demyelination syndrome (ODS) cases receiving IVIG or/and PP

\begin{tabular}{|c|c|c|c|c|c|c|c|}
\hline References & Involvement & Comorbidity & $\begin{array}{l}\text { HypoNa/ } \\
\text { rapid } \\
\text { correction }\end{array}$ & $\begin{array}{l}\text { Treatment } \\
(\mathrm{Rx})\end{array}$ & $\begin{array}{l}\text { Rx initiation } \\
\text { after } \\
\text { confirm }\end{array}$ & Dosage & Outcome \\
\hline \multirow[t]{3}{*}{ Bibl et al. [1] } & CPM & CAA & Yes/yes & $\mathrm{PP}$ & Immediately & $24,700 \mathrm{~mL}$ & $\begin{array}{l}\text { Complete motor } \\
\text { recovery, minimal } \\
\text { ataxia }\end{array}$ \\
\hline & CPM & N/A & Yes/no & $\mathrm{PP}$ & Immediately & $5243 \mathrm{~mL}$ & Walk with assistance \\
\hline & CPM & CAA & Yes/no & $\mathrm{PP}$ & Immediately & $18,270 \mathrm{~mL}$ & $\begin{array}{l}\text { Complete motor } \\
\text { recovery }\end{array}$ \\
\hline $\begin{array}{l}\text { Grimaldi } \\
\text { et al. [6] }\end{array}$ & CPM & CAA & Yes/yes & $\mathrm{PP}$ & N/A & $37,300 \mathrm{~mL}$ & Walk without assistance \\
\hline $\begin{array}{l}\text { Chang et al. } \\
\text { [7] }\end{array}$ & CPM & $\begin{array}{l}\text { Overdose of } \\
\text { sodium } \\
\text { bicarbonate }\end{array}$ & No/no & $\mathrm{PP}$ & N/A & $4394 \mathrm{~mL}$ & $\begin{array}{l}\text { Complete motor } \\
\text { recovery, mild } \\
\text { diplopia }\end{array}$ \\
\hline $\begin{array}{l}\text { Finsterer } \\
\text { et al. [8] }\end{array}$ & CPM & CAA & Yes/no & IVIG & 5 days & $\begin{array}{l}0.4 \mathrm{~g} / \\
\mathrm{kg} / \text { day } \times 5 \text { days }\end{array}$ & $\begin{array}{l}\text { Walk without assistance, } \\
\text { mild dysarthria and } \\
\text { ataxia }\end{array}$ \\
\hline $\begin{array}{l}\text { Deleu et al. } \\
\text { [9] }\end{array}$ & CPM, EPM & N/A & Yes/yes & IVIG & 7 days & $\begin{array}{l}0.4 \mathrm{~g} / \\
\mathrm{kg} / \text { day } \times 5 \text { days }\end{array}$ & $\begin{array}{l}\text { Improve in weakness } \\
\text { and eat independently }\end{array}$ \\
\hline $\begin{array}{l}\text { Mastrangelo } \\
\text { et al. [10] }\end{array}$ & CPM, ЕРM & $\begin{array}{l}\text { Rapid correction of } \\
\text { hypernatremia }\end{array}$ & $\mathrm{No} /$ no & IVIG & N/A & N/A & Near complete recovery \\
\hline \multirow[t]{3}{*}{$\begin{array}{l}\text { Murthy et al. } \\
\text { [11] }\end{array}$} & EPM & N/A & Yes/yes & IVIG & 1 day & 5 days & $\begin{array}{l}\text { Complete motor } \\
\text { recovery }\end{array}$ \\
\hline & EPM & Panhypopituitarism & No/no & IVIG & N/A & 5 days & $\begin{array}{l}\text { Complete motor } \\
\text { recovery }\end{array}$ \\
\hline & CPM, EPM & CAA & Yes/yes & IVIG & 7 days & N/A & $\begin{array}{l}\text { Moderate neurological } \\
\text { recovery }\end{array}$ \\
\hline \multirow[t]{2}{*}{$\begin{array}{l}\text { Ludwig et al. } \\
\text { [12] }\end{array}$} & CPM & $\begin{array}{l}\text { Post liver } \\
\text { transplant }\end{array}$ & Yes/no & PP, IVIG & 2 days & $\begin{array}{l}\text { PP } 21,870 \mathrm{~mL}, \text { IVIG } \\
0.4 \mathrm{~g} / \\
\mathrm{kg} / \text { day } \times 5 \text { days }\end{array}$ & $\begin{array}{l}\text { Complete motor } \\
\text { recovery }\end{array}$ \\
\hline & CPM & $\begin{array}{l}\text { Post liver } \\
\text { transplant }\end{array}$ & Yes/no & PP, IVIG & 2 days & $\begin{array}{l}\text { PP } 17,097 \mathrm{~mL}, \text { IVIG } \\
0.4 \mathrm{~g} / \\
\mathrm{kg} / \text { day } \times 5 \text { days }\end{array}$ & Walk without assistance \\
\hline $\begin{array}{l}\text { Saner et al. } \\
{[13]}\end{array}$ & CPM & $\begin{array}{l}\text { Post liver } \\
\text { transplant }\end{array}$ & No/no & PP, IVIG & N/A & $\begin{array}{l}\text { PP } 24,000 \mathrm{~mL}, \text { IVIG } \\
0.4 \mathrm{~g} / \\
\mathrm{kg} / \text { day } \times 5 \text { days }\end{array}$ & $\begin{array}{l}\text { Walk without assistance, } \\
\text { mild dysarthria and } \\
\text { ataxia }\end{array}$ \\
\hline
\end{tabular}

laboratory values had returned, the rapid correction had already occurred. A possible mechanism for hyponatremia correction in liver failure patients mentions heightened susceptibility to astrocyte metabolism resulting in abnormalities of blood-brain barrier function and a decreased ability to generate new intracellular osmoles in response to osmotic changes [2]. The mechanism of action in which PP and IVIG improve neurological outcome of ODS is unknown. One proposed theory is that myelinotoxic products are released after the osmotic stress insult and the burden maybe reduced by PP [1]. One other proposed theory is ODS may be a result of immunologic process, and thus IVIG treatment may help improve the outcome.

Radiologic studies in ODS can be negative during the first 4 weeks after the onset of clinical symptoms, and a negative imaging cannot exclude the presence of the disorder [3, 4]. Head CT typical findings are an area of hypodensity in the central pons, but this change is poorly sensitive [5]. The brain MRI is more reliable for diagnosing ODS. Typical findings for CPM are symmetric trident-shaped increase signals in the central pons on T2-weighted and FLAIR, and decreased signals in the T1-weighted images [3]. Diffusion weighted images can show a restricted diffusion pattern more rapidly, and can possibly be more useful for initial diagnosis. Being an uncommon condition, the standard of care consists mainly of supportive care to prevent complications including respiratory failure. An extensive literature search through PubMed for all reported cases of ODS receiving treatment of IVIG, PP, or both, with a total of nine articles were found and summarized (Table 1).

Drawing from available case reports, PP, IVIG, or the combination may provide treatment strategies for patients 
with ODS. Remarkable improvement has been seen as soon as 1 day post treatment and complete recovery of neurological function established in some patients. In our case of ODS post liver transplantation who was treated with IVIG and immunoglobulin, our patient showed suboptimal improvement in motor weakness compared to other reported cases. In most of the reported ODS cases successfully treated with IVIG and PP together, or either alone, treatment was initiated within the first week of symptom onset and less than 5 days after confirmation by imaging studies (Table 1). However, our patient was started on treatment 19 days after symptoms onset because of the delay in diagnosis after the initial MRI imaging was negative. We hypothesize the delay in treatment initiation contributed to a worse outcome. The usual clinical presentation of ODS is often irreversible neurological symptoms, and we believe that this is due to a time-sensitive damage from the myelinotoxic compound that may be reversible if the offending agent is removed in time with the treatment of PP and IVIG.

Acknowledgments AC Berry is the article guarantor. No financial support was obtained for the project. No financial grant was obtained. None of the authors listed received any financial support or services or any other contributions for their work. All patient identifiers have been removed.

\section{Compliance with ethical standards}

Conflict of interest The authors declare that they have no conflict of interest.

Statement of human and animal rights All procedures performed in studies involving human participants were in accordance with the ethical standards of the institutional or national research committee and with the 1964 Helsinki declaration and its later amendments or comparable ethical standards. This article does not contain any studies with animals performed by any of the authors.

Informed consent As with all case reports from my institution, waiver of informed consent was granted by the IRB.

\section{References}

1. Bibl D, Lampl C, Gabriel C, Jungling G, Brock H, Kostler G (1999) Treatment of central pontine myelinolysis with therapeutic plasmapheresis. Lancet 353(9159): 1155

2. Boon AP, Carey MP, Adams DH, Buckels J, McMaster P (1991) Central pontine myelinolysis in liver transplantation. J Clin Pathol 44(11):909-914

3. Martin RJ (2004) Central pontine and extrapontine myelinolysis: the osmotic demyelination syndromes. Neurol Neurosurg Psychiatry 75 Suppl 3:iii22-iii28

4. Howard SA, Barletta JA, Klufas RA, Saad A, De Girolami U (2009) Best cases from the AFIP: osmotic demyelination syndrome. Radiographics 29(3):933-938

5. Brunner JE, Redmond JM, Haggar AM, Kruger DF, Alias SB (1990) Central pontine myelinolysis and pontine lesions after rapid correction of hyponatremia: a prospective magnetic resonance imaging study. Ann Neurol 27(1):61-66

6. Grimaldi D et al (2005) Plasmapheresis improves the outcome of central pontine myelinolysis. J Neurol 252(6):734-735

7. Chang KY et al (2014) Plasma exchange successfully treats central pontine myelinolysis after acute hypernatremia from intravenous sodium bicarbonate therapy. BMC Nephrol 15:56

8. Finsterer $J$ et al (2000) Immunoglobulins are effective in pontine myelinolysis. Clin Neuropharmacol 23(2):110-113

9. Deleu D et al (2005) "Man-in-the-barrel" syndrome as delayed manifestation of extrapontine and central pontine myelinolysis: beneficial effect of intravenous immunoglobulin. J Neurol Sci 237(1-2):103-106

10. Mastrangelo $\mathrm{S}$ et al (2009) Central pontine and extrapontine myelinolysis in a pediatric patient following rapid correction of hypernatremia. Neuropediatrics 40(3):144-147

11. Murthy SB et al (2013) Osmotic demyelination syndrome: variable clinical and radiologic response to intravenous immunoglobulin therapy. Neurol Sci 34(4):581-584

12. Ludwig KP et al (2011) Plasmapheresis and intravenous immune globulin improve neurologic outcome of central pontine myelinolysis occurring post orthotopic liver transplant. Ann Pharmacother 45(2): e10

13. Saner FH et al (2008) Treatment of central pontine myelinolysis with plasmapheresis and immunoglobulins in liver transplant patient. Transpl Int 21(4):390-391 